\title{
USAGE OF IT TOOLS IN LOGISTICS SERVICES DESIGN - OPPORTUNITIES AND CHALLENGES
}

\author{
ANDRZEJ RZECZYCKI \\ University of Szczecin, Faculty of Management and Economics of Services, POLAND \\ e-mail: andrzej.rzeczycki@wzieu.pl
}

\author{
\begin{tabular}{l|l} 
RECEIVED & 12 September 2017
\end{tabular} \\ \begin{tabular}{l|l} 
ACCEPTED & 15 December 2017
\end{tabular} \\ JEL \\ CLASSIFICATION \\ L87, M2, 033 \\ KEYWORDS process design, logistics services, IT tools
}

ABSTRACT Artykuł ma za zadanie przedstawić możliwości wykorzystania narzędzi informatycznych służących modelowaniu procesów do projektowania usług logistycznych. Przedstawione opracowanie koncentrować się będzie na możliwościach systemu ADONIS, udostępniane w wersji on-premise oraz SaaS, wskazując możliwości symulacyjne oraz analityczne tych rozwiązań. Obiektem analizy będą zaś procesy usługowe świadczone przez operatorów 3PL.

The article has to present the possibilities of using IT tools to model processes for the design of logistics services. This paper will focus on the capabilities of ADONIS system, in on-premise and SaaS versions, indicating the simulations and analytical capabilities of these solutions. The object of this analysis will be the services processes provided by 3PL operators.

\section{Introduction}

Design is understood in two ways: as a phase that comes after concept generation and testing and business analysis, or as a phase that generating new concepts and new knowledge (Kimbell, 2011, pp. 41-52). According to E.V. Krick the design process involves activities and events that occur between the appearance of the problem and the development of documentation that will describe the solution to the problem, satisfactory from a functional, 
economic and other requirements (Krick, 1975, pp. 129-130). Each design process is based on a specific scheme of research methodology that deals with both diagnostics and design. In each case, this scheme should be properly modified and adapted to the requirements (Stabryła, 2007, pp. 178-179). Nevertheless, in the design process of the service, we can distinguish the phase of analytical-research work and the phase of elaboration of the main project. In the framework of analytical-research work in the design of services, methods and techniques are used: Quality Function Deployment, Customer Satisfaction Index, Customer Incident Techniques, SERVQUAL - Service Quality, Customer Journey Map, Contextual Interviews, $5 x$ Why. The development of the main project is based on the creating of variants of the service processes, while retaining the goals and values identified during researchanalytical work (Dietrich, Trischler, Schuster, Rundle-Thiele, 2017, pp. 663-668; Lin, Hughes, Katica, Dining-Zuber, Plsek, 2011, pp. 73-86).

The paper presents the possibilities and challenges of information systems used in process modeling (on the example of ADONIS), and so creating a main service design, identified during the design work carried out in the company providing logistic services. The aim of the article is to indicate the universality of the methods and tools used, which ensure transparency and quick and easy analysis.

\section{IT process modeling tools}

The use of BPMN in the design of process analysis and BPMN notation is widely disseminated in the available scientific literature (Aalst, La Rosa, Santoro, 2016, pp. 1-6; Prades, Romero, Estruch, García-Dominguez, Serrano, 2013, pp. 115-122). With the growing interest in the problem of modeling processes on the market, a number of IT tools have emerged which allow us to prepare a model of the processes under study. Process modeling tools can be divided into (Żytniewski, Zadora, 2017, pp. 195-210):

- simple modeling tools for visualizing and mapping processes, such as MS Office Visio, Flowcharter (Micrografx), Bizagi Process Modeler,

- Computer Aided System Engineering (CASE) tools for process modeling, where they are integrated with IT solutions such as Oracle Designer/2000, Enterprise Architect,

- advanced design and development tools for in-depth analysis and simulations, such as ADONIS, ARIS, iGrafix.

Trends in the development of information systems for process modeling are aimed at creating environments with far greater functionality than modeling processes. Traditional modeling tools are enriched with the ability to perform analyzes and simulations on the developed model. These solutions allow to present alongside business process definitions, as well as other models such as organizational structure, resources, documents, IT systems, etc. The extended range of modeling areas combined with the capabilities of computer simulation allows to evaluate time, cost and efficiency of processes.

Among solutions with such a wide spectrum of modeling and process analysis is the ADONIS system, implemented and developed by BOC Information Technologies Consulting (BOC, 2017). ADONIS offers comprehensive support for process management: from organization and process descriptions, through process optimization to continuous monitoring of goals. With components for modelling, analysis, simulation and evaluation, user can create multidimensional models of business processes, perform statistical analysis of developed process models, and keep track of their processes. System components include: acquisition (import and export of data between ADONIS and Excel spreadsheet), modeling (development of multidimensional business process models), 
analysis (static analysis of developed models using predefined queries or user-created queries), simulation (conducting experiments on a model to describe, explain or predict the behaviour of the real system), evaluation (current monitoring of processes by supplementing the model with KPI values), import/export (importing and exporting models from and into the ADONIS environment). ADONIS is fully functional thanks to the ability to create multiple types of models that are interconnected. The BPMS library in ADONIS includes the following models: process map, business process model, work environment model, product model, documents model, IT systems model, risk model, control model, resources model, data's model, use case model, BPMN model (Gawin, Marcinkowski, 2013, pp. 29-34).

A wide range of functionality of ADONIS system allows to model the study environment and to analyse and simulate: processes, costs, resource utilization, personnel management, documentation management, risk management. The result of the simulation and analysis conducted is the design process/service, which should be tested, and after a positive test result, implemented.

The latest version of ADONIS NP is a cloud-based solution. This increases system and data availability, facilitates the dissemination of information, enables scalability and personalization. In addition, the new version introduced an integrated search mechanism and extended module analyses.

\section{Designing logistics services in the ADONIS environment - an example of application}

The presented case concerns a Polish company providing logistics services. As part of the project carried out after consultation with customers, the company decided to redesign their processes to automate office service - the introduction of WMS along with automated identification. The project was carried out with the participation of the university.

The basic service provided by the company is warehousing, which, according to theory, consists of four basic processes: receving, storage, picking and shipping. Each of these processes was analysed (creating an as-is map) and re-modeled (to-be maps) taking into account the requirements of the company's employees and their clients. The improvement was a new information flow system that eliminated paperwork and accelerated customer service (information about inventory, free space and carried out operations transferred in real time). It also simplified the process considerably, due to the focus of most operations directly on the warehouse (in the as-is version the entire transport documentation was created only after the warehouse operations, since it was only then possible to determine exactly which goods were picked for release). Shipping service designed in ADONIS system are presented in Figure 1.

Customer service in the company is dealt by merchants, documentation preparation and control of storage areas by logistics specialists, and direct handling of the goods by warehouse staff. In the presented version of the to-be model, the paper circulation of the document was completely eliminated. The electronic version of the documentation is prepared at the time of acceptance of the order. The "to be" model assumes the processing of information by changing the status of the created documents in the WMS system. Completely closing the document will mean the end of the process and the departure of the driver to the gate.

The significant problem was the new division of duties, especially at the junction of the warehouse and office. The staff of the office did not know how to arrange and issue the goods in the warehouse (it was finally determined that it was issued in accordance with the FIFO principle, taking into account the possibility of easy access to the goods). The new process introduced a fixed system of goods placement and the need to create 


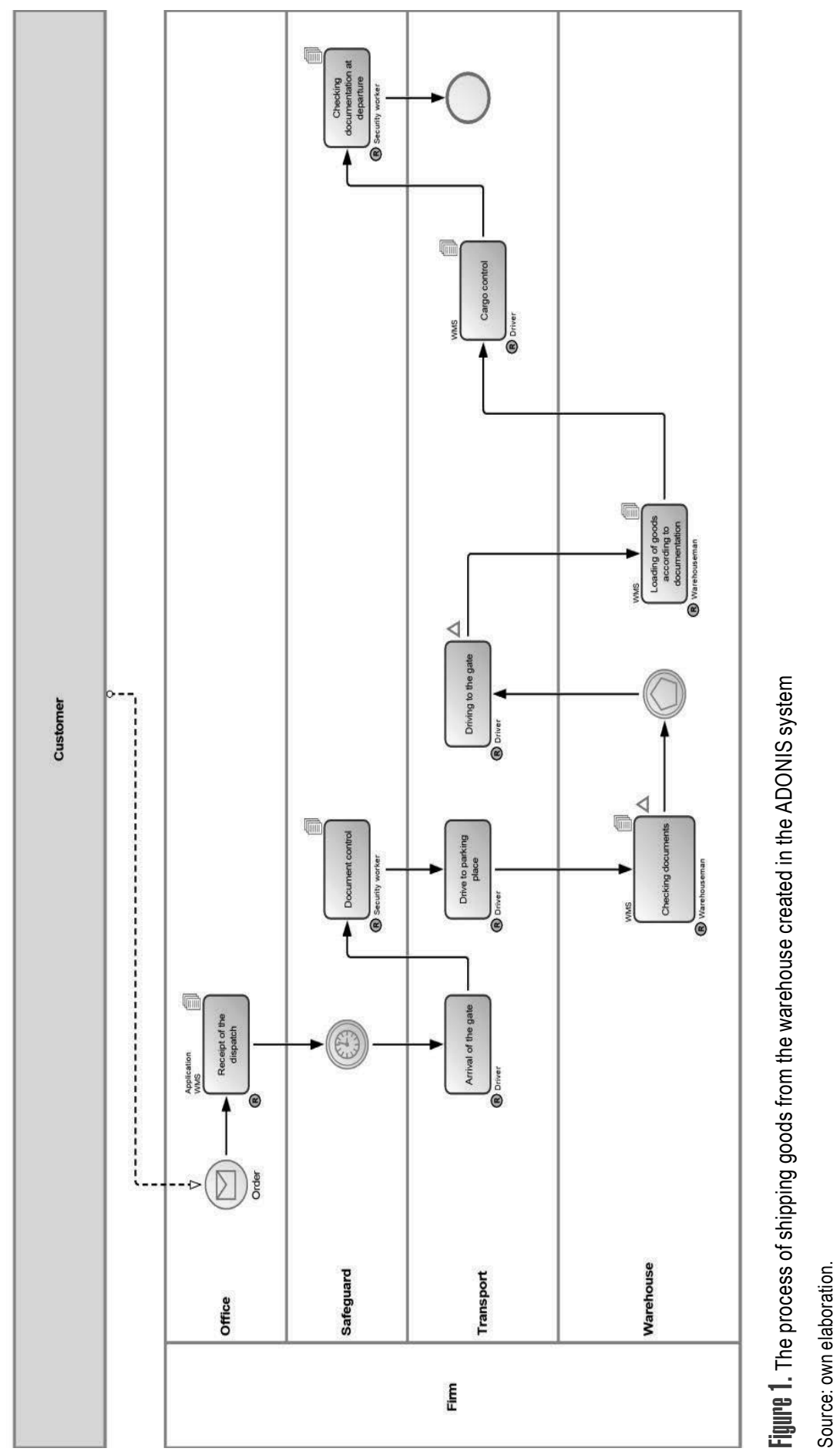


labels by a magazine employee. This has greatly facilitated the work of logistics specialists, but has encountered considerable resistance from the warehouse staff. Logistic specialists handled the documentation from the WMS system, and the warehouse staff had to learn how to operate the internal bar code system and in minimize way the functionality of the WMS. The model of the target system is presented in Figure 2.

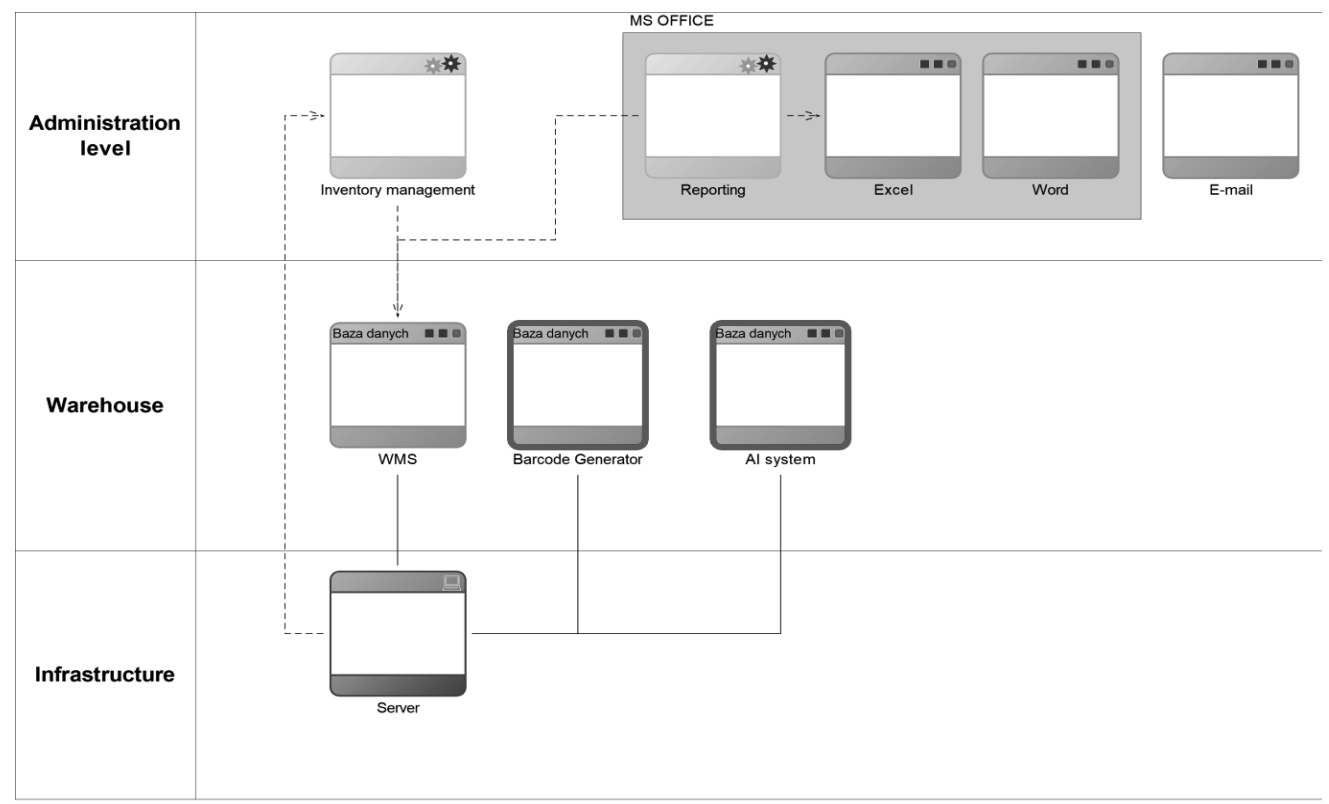

Figure 2. The IT system model of the analysed firm made in the ADONIS system

Source: own elaboration.

The document circulation system has been completely changed. Paper documents have been eliminated until the goods are released from the warehouse, where the approved document is printed for customer and accounting purposes. After consultation with the main clients, the design of the document was also unified to include the necessary information, such as commodity index of the customer or packaging schemes. The target documentation system is shown in Figure 3. In addition, to facilitate document workflows and inventory searches, the internal labelling system was based on commodity index of the customer.

Process analysis and simulation were performed using path analysis and workload analysis with accounting analysis elements. The path analysis allows you to calculate the process execution time for a given path, the waiting time, the storage time, the transport time, and the total process time and cost. The total time for the modeled shipping process was 1 hour and 12 minutes for one 24-pallet truck. 


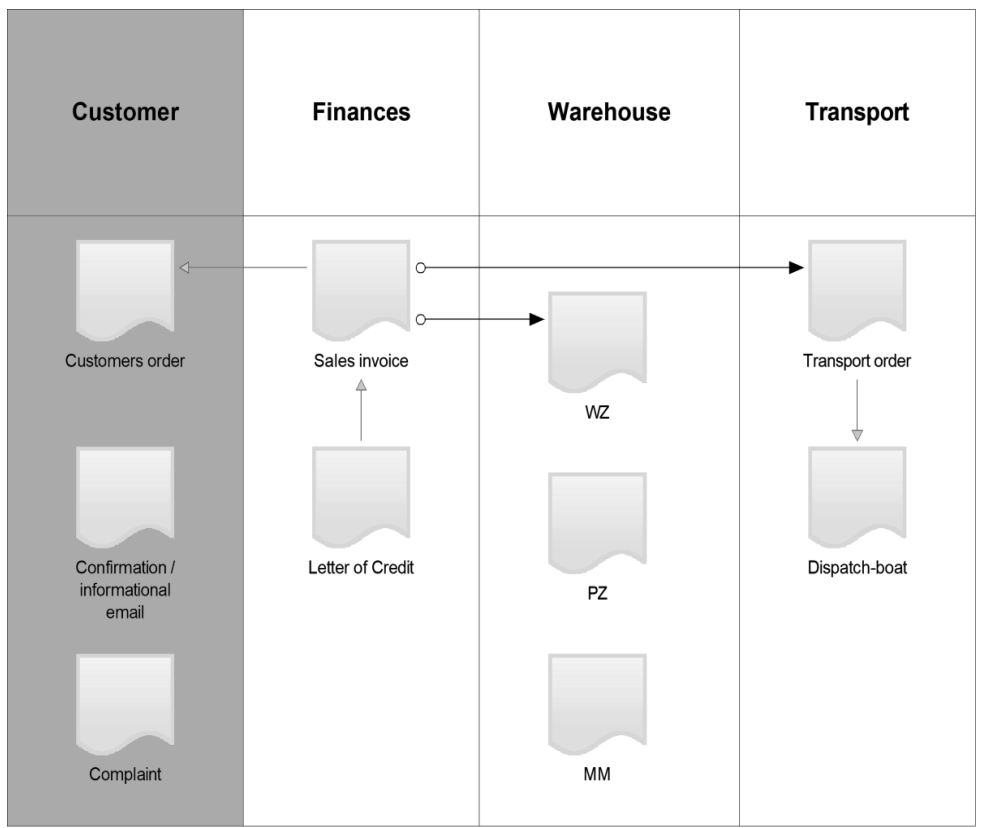

Figure 3. The document model of the analysed firm made in the ADONIS system

Source: own elaboration.

The program's simulation module also allows for stationary and non-stationary analysis of employee use and workload analysis. The system also allows for comparative workload analysis for several processes at once, allowing for a quick comparison of "as is" and "to be" processes. Usage analyses allow identifying bottlenecks, but in contrast to workload analysis, there are no limiting parameters such as length of working day. ADONIS system allows to perform the analysis of the load of the process, employee, work environment or the need for personnel. In the analyzed case (assuming 170 working days per year and 8 hour shift), the most burdened worker is the forklift operator (too few operators on shift) and the least warehouse manager, whose work related to the shipping processes engages him monthly for 3 days and 4 hours. For the purposes of the analysis, hourly wage rates based on market data were also introduced. On this basis, the total monthly personnel costs associated with releases in the company were calculated, which in the to-be model amounted to 1253 euros.

\section{Conclusion}

IT tools for business process modeling are gaining in popularity both as dedicated solutions and as components of other systems such as ERP (Enterprise Resource Planning). The most common reason for using them is the desire to increase the transparency of the process, to introduce technological changes, or to change the flow of information. The ADONIS system that extends the BPMN notation with additional models reference is included in this trend. In this way, it not only modeling the process and identifying the resources and information used, but also linking the infrastructure, the organizational structure and the documents and information systems used. This makes it easier to detect resource wastage and avoid suboptimalisation in their planning. 
Using the tool will not help much if the appropriate organization and the substantive design of the process are provided. Particularly important elements during the preparation of the project are: proper designation of the objectives of the project/process, internal and external integration of the inputs and outputs of the processes, determining the hierarchy of the problems to be solved, avoiding suboptimization, determining methods of data collection and use (including quantitative data) and the correct interpretation of the results of the analyzes. Creating a service / process model is labor-intensive and based on the experience and knowledge of the project manager, but it provides a number of benefits including transparency and simplicity, the ability to monitor change, understand the contribution of individual units to performance, and launching hidden productivity gains.

\section{Reference}

Aalst, W.M.P., La Rosa, M., Santoro, F.M. (2016). Business Process Management. Don't Forget to Improve the Process! Business \& Information Systems Engineering, 58 (1), 1-6.

Boc (2017) Adonis. Retrieved from: https://pl.boc-group.com/adonis (10.08.2017).

Dietrich, T., Trischler, J., Schuster, L., Rundle-Thiele, S. (2017). Co-designing services with vulnerable consumers. Journal of Service Theory and Practice; Bingley, 27 (3), 663-688.

Gawin, B., Marcinkowski, B. (2013). Symulacja procesów biznesowych. Standardy BPMS i BPMN w praktyce. Gliwice: Helion.

Kimbell, L. (2011). Designing for service as one way of designing services. International Journal of Design, 5 (2), 41-52.

Krick, E.V. (1975). Wprowadzenie do techniki i projektowania technicznego. Warszawa: WNT.

Lin, M.C., Hughes, B.L., Katica, M.K., Dining-Zuber, Ch., Plsek, P.E. (2011). Service Design and Change of Systems: Human-Centered Approaches to Implementing and Spreading Service Design. International Journal of Design, supl. Special Issue; 5 (2), 73-86.

Prades, L., Romero, F., Estruch, A., García-Dominguez, A., Serrano, J. (2013). Defining a Methodology to Design and Implement Business Process Models in BPMN according to the Standard ANSI/ISA-95 in a Manufacturing Enterprise. Procedia Engineering, $63,115-122$.

Stabryła, A. (2007). Aspekty interpretacyjne i metodologiczne zarządzania projektami. Zeszyty Naukowe MWSE w Tarnowie, 9 , 161-181.

Żytniewski, M., Zadora, P. (2013). Modelowanie procesów biznesowych z użyciem notacji BPMN. Studia Ekonomiczne - Wyzwania w rozwoju podstaw metodycznych projektowania systemów informatycznych zarządzania, 128, 195-210.

Cite this article aS: Rzeczycki, A. (2018). Usage of IT tools in logistics services design - opportunities and challenges. European Journal of Service Management, 1 (25), 259-265. DOI: 10.18276/ejsm.2018.25-32. 